Альошин Г.В. Украӥнська державна академія залізничного транспорту

Коломійцев О.В., Бабенко В.П. Військовий інститут танкових військ Національного технічного університету "Харківський політехнічний інститут"

Топчій В.Л. Наџіональна академія начіональної гвардї̈ Украӥни

Олійник Р.М. Державний науково-дослідний інститут випробувань $і$ сертифікаиії озброєння та військової техніки

\title{
МЕТОД ОПТИМАЛЬНОГО СИНТЕЗУ ІНФОРМАЦІЙНО-ВИМІРЮВАЛЬНИХ СИСТЕМ
}

\begin{abstract}
У статті акцентовано увагу на існуючу проблему оптимального синтезу (побудови) інформаційновимірювальних систем (IBC). Показано шляхи вирішення иієї проблеми за рахунок використання кривих обміну за Гуткіним Л.С. За допомогою яких можливо пояснити, які ІВС оптимальніші за своїми параметрами, як погоджувати показники якості вимірювань параметрів, як здолати потребу у великій апріорній невизначеності, не зменшуючи точності вимірювань, як пояснити суперечність деяких відомих теорій, як погоджувати апріорний діапазон з фізичним діапазоном, як використати отримані апріорні дані, як впливає на точність вимірювань змінний рівень сигналу, як впливає точність налаштування на точність вимірювань, як можна скоротити час пошуку сигналу, як впливає на автоматичне супроводження характер процесу, щзо стежить, тощо. Запропонований метод оптимального синтезу IВС справедливий для IВС будь-якого типу за сигналами, щзо використовуються, та різних параметрів, щзо вимірюються.
\end{abstract}

Ключові слова: оптимізація, оцінка параметра, вимірювання, точність.

\section{Постановка проблеми}

На даний час, відомі андріметрологічні методи вимірювань здійснюють порівняння параметра, що вимірюється, з відповідним еталоном. Для радіоелектронних вимірювань це нуль-метод, різницевий метод та ін., яких вже недостатньо для радіо- і оптико-електронних вимірювань, де потрібні:

- високі точності оцінки апріорних даних;

- швидкість (час) вимірювань;

- довірча ймовірність зістиковки шкал;

- відношення потужностей сигналу до шуму;

- кошти для побудови інформаційно-вимірювальних систем (IBC);

також метод оптимального синтезу IBC із загальних позицій (параметрів, характеристик), тощо [1, 3-5].

Перелічені потреби є основою загальної проблеми оптимального синтезу IBC. Дану проблему можливо вирішити завдяки використанню узагальнюючого виразу для одержання кривих обміну цільової функції за Гуткіним Л.С. [1]. Отже, для вирішення часткових задач, що входять до складу проблеми оптимального синтезу IBC та отримання кривих обміну, цільову функцію можна знайти для всіх типів IBC. Часткові задачі оптимального синтезу IBC можливо сформувати, якщо знайти обмеження за вартістю, піковою потужністю, тощо.

Таким чином, формулювання узагальненого показника якості для оптимального синтезу IBC з єдиних позицій є актуальною науковою проблемою.

Аналіз останніх досліджень і публікацій

У [1], при розв'язанні часткових задач оптимального синтезу радіоелектронних пристроїв, розкривається особливість їх оптимального вирішення. Тобто, якщо поступово змінювати показники обмеження i вирішувати задачу оптимального синтезу радіоелектронних пристроїв за головним показником, то можливо отримати взаємозалежність між оптимальними показниками - кривою обміну цільової функції. Отже, отримуємо ряд часткових задач оптимізації параметрів лише для радіоелектронних 
пристроїв, що вирішуються.

За результатами проведеного аналізу існуючих альтернативних теорій вимірювань встановлено, що у відомій літературі [2] за темою теорії радіоелектронних вимірювань зустрічаються як метод функціоналу правдоподібності (ФП) за Вудвордом Ф.М. і поняття “потенційноі” точності вимірювань, що викликають питання, так і фрагменти теорії радіоелектронних вимірювачів, де немає центральної ідеї оцінки якостей для оптимального синтезу IBC, а також відсутній системний аналіз впливу суттєвих факторів, діючих на самі вимірювачі IBC.

Помилка Вудворда Ф.М. полягає у тому, що параметр $\lambda_{u}$ (затримка у часі), який передавався - відомий, а параметр у суміші - невідомий. Такого припущення робити не можна тому, що різниця параметрів у сигналі і у суміші сигналу з шумом не повинна бути, бо ця різниця суміші і сигналу повинна дорівнювати шуму. Тобто, у сигналі в суміші і у сигналі, що віднімається повинен бути один і той же параметр. Інакше не буде нормального розподілу шуму, що призводить до даного парадоксу.

У [3 - 6] оптимізація ряду часткових задач за параметрами систем радіо діапазону довжин хвиль, взагалі, здійснюється методом сепарабельного програмування, що дозволяє отримати рішення в аналітичному вигляді, яке дає криві обміну цільової функції.

Таким чином, необхідні рішення часткових задач оптимального синтезу IBC та отримання кривих обміну цільової функції можливо знайти для всіх типів IBC, якщо сформувати (сформулювати) часткові задачі оптимального синтезу (оптимізаціi) та знайти обмеження за вартістю, піковою потужністю сигналу тощо. Розв'язання загальної проблеми оптимального синтезу будь-якого типу IBC можливо на етапі отримання кривих обміну цільової функції. Тобто, необхідно сформулювати узагальнений показник якості IBC 3 єдиних позицій.

\section{Виклад основного матеріалу}

В IBC основними вимірювачами можуть бути аналогові та цифрові детектори, дискримінатори, перетворювачі параметрів у складі каналу автоматичного супроводження об'єкту або у складі каналу автоматичного супроводження за параметром. Але, супроводження швидкості вимірювання та перебудова даного каналу повинні бути не менше швидкості зміни процесу. Вимірювання або перетворення будь-якого параметра реалізується на основі відповідної функціональної залежності відліку від вимірюваної величини за відомим законом природи. При цьому необхідна найбільша чутливість вимірювача до параметра, що вимірюється, тому:

- для вимірювання частоти сигналу використовується чутливе явище резонансу;

- для вимірювання кутів азимута і місця використовується діаграма спрямованості (ДС) IВC;

- для вимірювання затримки часу використовується імпульс або його фронти;

- для вимірювання затримки випадкових процесів використовується автокореляційна функція, тощо.

Дані залежності беруться 3 відповідних сигнальних функцій вимірювача або 3 їх частин і комбінацій. Залежність для перетворення у відлік звуть шкалою. Точкова оцінка вимірювання за шкалою є результатом ii порівняння з відповідним еталонним значенням. При цьому, шкала має бути достатньо стабільною у розмірі і за настройкою. Тоді отриманий відлик відповідає заданій середньоквадратичній похибці, яка в процентах - це клас точності.

Відомі функціональні вимірювачі, де закон перетворення записується у вигляді функціональної залежності (“прямопоказуючі” вимірювачі). Шкала може бути лінійною або ні. Лінійна більш бажана, тому що середньоквадратична похибка не змінюється за всією шкалою. Для того, щоб виявити взаємозв'язок показників якості вимірювачів, важливо розглянути (рис. 1). 


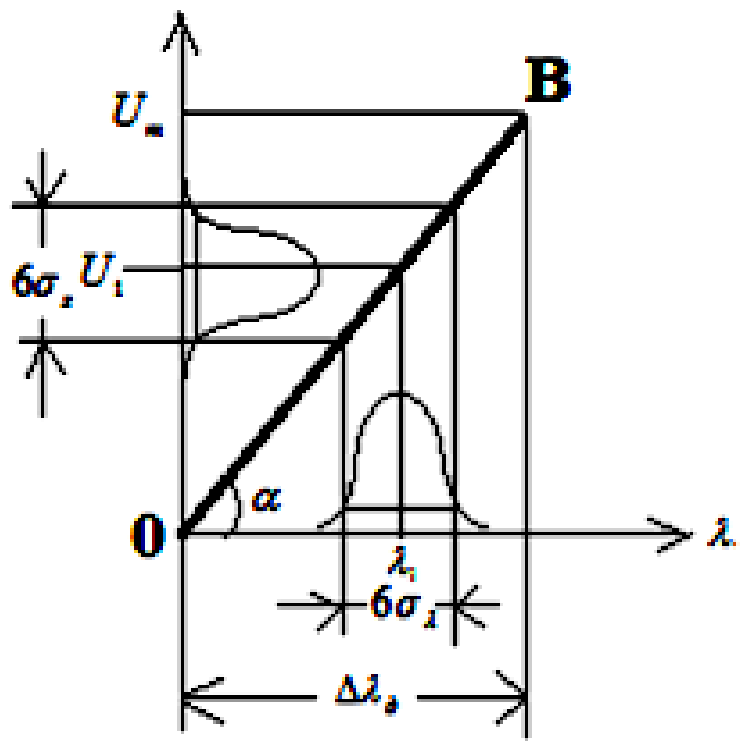

ISSN 2706-7386

Рис. 1. Характеристика 0B - шкала вимірювача IBC

На рисунку 1 позначено наступне: $6 \sigma_{3}$ - довірчий інтервал завади; $6 \sigma_{\lambda}-$ довірчий інтервал параметру; $U_{m}, U_{1}, \lambda_{1}, \Delta \lambda_{\partial}$ - відповідно: діапазон відліків, відлік, оцінка параметра та апертура (діапазон) вимірювача IBC.

Показники якості (оптимізації) вимірювача IBC.

Точність буде постійною, якщо характеристика 0В лінійна, як на рисунку 1. Якщо вимірюється параметр $\lambda_{1}$, то на виході з'явиться напруга $U_{1}$. При цьому, вимірювання сигналу отримується із завадою. Знаючи точність вимірювання, визначаємо довірчий інтервал $6 \sigma_{3}$ і $6 \sigma_{\lambda} .3$ рисунку 1 можливо заключити, що справедливе відношення:

$$
6 \sigma_{\lambda}=6 \sigma_{\tau}=\frac{6 \sigma_{3}}{\operatorname{tg} \alpha}
$$

Відношення (1) можливо записати наступним чином:

$$
\sigma_{\lambda}^{2}=\frac{\sigma_{3}^{2}}{\operatorname{tg}^{2} \alpha}=\frac{\sigma_{3}^{2}}{\left(U_{\lambda}^{1}\right)^{2}}
$$

або:

$$
\sigma_{\lambda}^{2}=\frac{\sigma_{3}^{2}}{\frac{U_{m}^{2}}{\left(\Delta \lambda_{\partial}\right)^{2}}}=\frac{\left(\Delta \lambda_{\partial}\right)^{2}}{q}=\frac{\left(\Delta \lambda_{\partial}\right)^{2}}{\frac{P_{m}}{N_{0} \Pi}},
$$

де $q=\frac{U_{m}^{2}}{\sigma_{3}^{2}}=\frac{P_{m}}{P_{3}}=\frac{P_{m}}{N_{0} \Pi}-$ відношення потужностей максимуму сигналу до завади, $N_{0}-$ спектральна щільність завади, п- смуга пропускання частот вимірювача IBC.

Таким чином, для оптимального вибору вимірювача IBC, його якостей, структури $\mathrm{i}$ алгоритму достатньо п'яти основних показників:

1) точності;

2) апріорного діапазону;

3) часу вимірювання, який обмежується смугою пропускання П;

4) надійності (квантіля) підстройки (стиковки шкал часу);

5) рівня сигналу (відношення потужностей сигналу до завади) або вартості.

Можна стверджувати, що вираз (3) $є$ основою для логічного зв'язку існуючих, 3 новими методами розвитку, вимірювачів IBC 3 будь-якими якостями $\mathrm{i}$ діапазонами 
вимірювання:

- дискримінаторні вимірювачі;

- пошукові або панорамні вимірювачі;

- багатоканальні вимірювачі;

- багатошкальні вимірювачі;

- багатоетапні вимірювачі;

- цифрові вимірювачі;

- комбіновані вимірювачі.

Отримані результати якості розповсюджених дискримінаторних вимірювачів можуть входити до кривої обміну цільової функції та є основою для використання в складних IBC.

Вимірювачі IBC можуть бути окремі або у складі відповідних вимірювальних (інформаційного) каналів та каналу автоматичного супроводження об'єкту (параметру).

За допомогою виразу (3) отримуються універсальні результати, які можуть стати основою оптимізації синтезу IBC, що, також, можливо віднести до будь-якого параметру, який вимірюється.

Відомо, що сигнал повинен бути значно більшим, ніж шум. Тому, при такій підміні параметрів, слабкий шум підмінюється великою різницею потужних сигналів 3 різними параметрами. Дана обставина означає неправомірне призначення різниці параметрів, з якої можна отримати, що завгодно, у тому числі некоректно отриману функцію автокореляції (ФАК) сигналу. Для отримання якої не потрібен ФП, тому що відома узгоджена фільтрація. Ось тут, можливо, акцентувати увагу на головну помилку послідовників Вудворда Ф.М. [2], яка полягає у тому, що: звідсіля можна (але неправомірно) отримати алгоритм вимірювань, “потенціальну” точність, “оптимальні” сигнали і параметри для складних і різних векторних моделей параметрів і сигналів. Такий ФП не підтримують також наступні факти:

- у вимірювачах, що слідкують (здійснюють автоматичне супроводження за параметром), взагалі необов'язково використовувати автокореляційну функцію сигналу та ще й при їі максимальному значенні;

- цифрові вимірювачі також працюють за іншими принципами;

- багатошкальні вимірювачі взагалі не вкладаються у цю теорію;

- підвищення точності вимірювань затримки сигналу залежить від широти спектру, але це зрозуміло не 3 цієї теорії потенціальної точності, а з фактом підвищення крутизни фронтів сигналу на виході приймача.

Необхідно відмітити, що взагалі в метрології крутизну шкали називають чутливістю, а вона визначає точність вимірювань. Тому, крутизна найбільша не у центрі автокореляційної функції.

За результатами проведеного аналізу поняття “потенційної” точності в радіоелектроніці, яке вступає у протиріччя з існуючими методами вимірювання, встановлено наступне. В існуючих відомих роботах доведено, що це поняття недоцільно використовувати для оцінки точності у радіовимірювальних системах. Однак, показано, що поняття “потенційної точності" вимірювання має сенс, але лише для задач визначення точності розрізнення сигнальних функцій (СФ):

$$
\sigma^{2}=\frac{1}{q \psi^{\prime \prime}(0)}
$$

де $q$ - відношення сигнал/шум; $\Psi(\lambda)=\Psi(0) \psi(\lambda)$ - сигнальна функція; $\Psi(0)$ - максимум сигнальної функції, $\psi^{\prime \prime}(\lambda)$ - друга похідна від нормованої сигнальної функції у максимумі.

Відмічено, що вираз (4) не можливо застосовувати для звичайного прямокутного сигналу, для якого $\psi^{\prime \prime}(0)$ безкінечна. Тоді, для розрізнення сигнальних функцій потрібно мати форму сигналу за типом перевернутої кнопки. Але (4) можливо використовувати для оцінювання здвигу сигналу за часом або за кутами для розрізнювання сигналів в радіолокаторах. 
Сигнальна функція - гострий відлик сигналу на виході приймача. При вимірюванні параметра затримки часу у якості СФ може бути, наприклад, сигнал, який випромінюється у формі автокореляційної функції, для параметрів виміряних кутів розташування об'єкту може бути огинаюча вихідного сигналу, яка отримана за рухом ДС, для частоти, що вимірюється, використовується резонансний ефект тощо.

Усічений ряд Тейлора можливо записати, як:

$$
\Psi(\lambda)=\Psi\left(\lambda_{0}\right)+\Psi^{\prime}\left(\lambda_{u}\right)\left(\lambda-\lambda_{0}\right)+\Psi^{\prime \prime}\left(\lambda_{0}\right) \frac{\left(\lambda-\lambda_{0}\right)^{2}}{2 !}+\ldots
$$

Проведемо апроксимацію верхівки СФ квадратичною залежністю в околиці параметру $\lambda_{0}$, утримуючи з точністю в 1 \% сталу крутизну квадратичного члена в інтервалі:

При цьому, лінійний член:

$$
\Delta \lambda \leq 0,03 \frac{\Psi^{\prime \prime}}{\Psi^{\prime \prime \prime}} .
$$

$$
\Psi^{\prime}\left(\lambda_{0}\right)\left(\lambda-\lambda_{0}\right)=0
$$

за визначенням та:

$$
\Psi^{\prime \prime}\left(\lambda_{0}\right)<0 \text {. }
$$

Фізична модель передбачає наявність двох цілей, коли одна СФ настроєна на параметр $\lambda_{0}$, а друга - на $\lambda_{1}$, або це одна СФ при деякій розстройці параметра $\lambda_{1}$ на інерційному екрані, яку слід визначити. Тоді, сумісний вплив СФ можливо записати як:

$$
\begin{aligned}
& \Psi_{0}\left(\lambda-\lambda_{0}\right)+\Psi_{1}\left(\lambda_{1}-\lambda\right)=\Psi_{0}\left(\lambda_{0}\right)+\Psi_{1}\left(\lambda_{1}\right)- \\
& -\left|\Psi_{0}^{\prime \prime}\left(\lambda_{0}\right)\right| \frac{\left(\lambda-\lambda_{0}\right)^{2}}{2 !}-\left|\Psi_{1}^{\prime \prime}\left(\lambda_{1}\right)\right| \frac{\left(\lambda_{1}-\lambda\right)^{2}}{2 !} .
\end{aligned}
$$

Отже, найбільший розмір прогалини, що віднімається, маємо при:

$$
\lambda_{\min }=\frac{\Psi_{0}^{\prime \prime} \lambda_{0}+\Psi_{1}^{\prime \prime} \lambda_{1}}{\Psi_{0}^{\prime \prime}+\Psi_{1}^{\prime \prime}}
$$

Ідеальний канал автоматичного супроводження (спостерігач) IBC за наявності завади зможе оцінити зсув параметра $\lambda_{1}$ відносно $\lambda_{0}$, за умови, якщо розмір прогалини - це від'ємна частина виразу (6) у загальній СФ при деякій розстройці стане не менше фону шумів, що розглядаються.

Проводимо оцінку зсуву параметра $\mathrm{CB}$ за появи прогалини при $\lambda=\lambda_{\min }$ за умов наявності шумів з наступного виразу:

$$
-\left|\Psi_{0}^{\prime \prime}\left(\lambda_{0}\right)\right| \frac{\left(\lambda-\lambda_{0}\right)^{2}}{2 !}-\left|\Psi_{1}^{\prime \prime}\left(\lambda_{1}\right)\right| \frac{\left(\lambda_{1}-\lambda\right)^{2}}{2 !}=\sigma_{u}^{2} .
$$

Оскільки:

$$
\lambda_{\text {min }}-\lambda_{0}=\frac{\lambda_{1}-\lambda_{0}}{2}
$$

та:

$$
\lambda_{1}-\lambda_{\min }=\frac{\lambda_{1}-\lambda_{0}}{2}=\frac{\Delta \lambda}{2}
$$

при можливому лівому відхиленні $\lambda_{1}$ буде: $2 \Delta \lambda=\sigma_{\lambda}$. 
Таким чином, при $\Psi_{0}^{\prime \prime}=\Psi_{1}^{\prime \prime}$, можливо записати (6) у наступному вигляді:

$$
\Psi_{0}^{\prime \prime} \sigma_{\lambda}^{2}=\sigma_{u}^{2}
$$

або:

$$
\sigma_{\lambda}^{2}=\frac{\sigma_{u}^{2}}{\Psi_{0}^{\prime \prime}}=\frac{\sigma_{i}^{2}}{\Psi(0) \psi^{\prime \prime}(0)}=\frac{1}{q\left|\psi^{\prime \prime}\right|} .
$$

Визначено, що спостереження параметру $\lambda$ за положенням максимуму СФ, та можливою оцінкою іiі зсуву за параметром з точністю (9) лише при виявленні прогалини. Таке спостереження у техніці (автоматиці) зветься за принципом “максимуму”, або екстремальним регулюванням. Воно відоме, також, при “полюванні на лис" у радіоспорті тощо. Але, таке спостереження не дає оцінку сторони відхилення та має значну похибку за (9), (рис. 2).

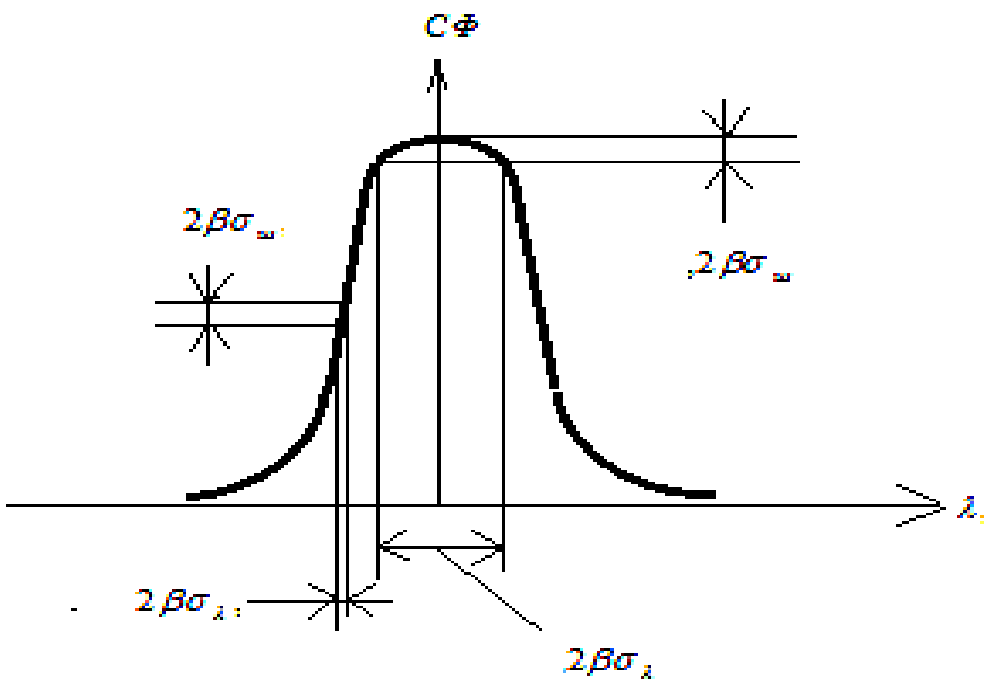

Рис. 2. Довірчі інтервали

На рисунку 2 зображені довірчі інтервали відповідно шуму та оцінки параметрів $2 \beta \sigma_{u}, 2 \beta \sigma_{\lambda}$, для двох варіантів настройки СФ (екстремальне оцінювання гірше методу оцінювання параметру при більшій боковії крутизні СФ). Отже, зрозуміло, що з метою оцінювання параметра вимірювача IBC краще мати найбільшу чутливість (на рівні найбільшої крутизни СФ), ніж екстремальне спостереження за СФ.

Таким чином, можливо стверджувати наступне:

- екстремальне спостереження найбільш корисне для розрізнення мети, а для оцінки параметру воно не діє, тому що найбільша чутливість і точність має бути при оцінці за найбільшою крутизною;

- похибка параметру для розрізнення може розраховуватись за (9), якщо відома кривизна СФ;

- завдяки (9), з точки зору розрізнення, бажано мати СФ з найбільшою кривизною у максимумі, але при цьому потрібна небажано велика смуга частот для часового процесу, велика антена для кутового процесу та велика добротність резонансу для частотного процесу.

Проведемо аналіз фактору узгодженості апріорного діапазону вимірювача IBC 3 його фізичним діапазоном, тобто, з апертурою двоканального дискримінатора, коли:

$$
2 \beta_{a \lambda} \sigma_{a \lambda}<2 \Delta \lambda_{\partial},
$$

де $\beta_{a \lambda}$ - апріорний квантіль апріорного діапазону $\Delta \lambda_{D}$, який дорівнює $2 \beta_{a \lambda} \sigma_{a \lambda}$ та менше фізичного діапазону $2 \Delta \lambda_{\partial}$, тобто менше апертури двоканального дискримінатора (рис. 3 ). 


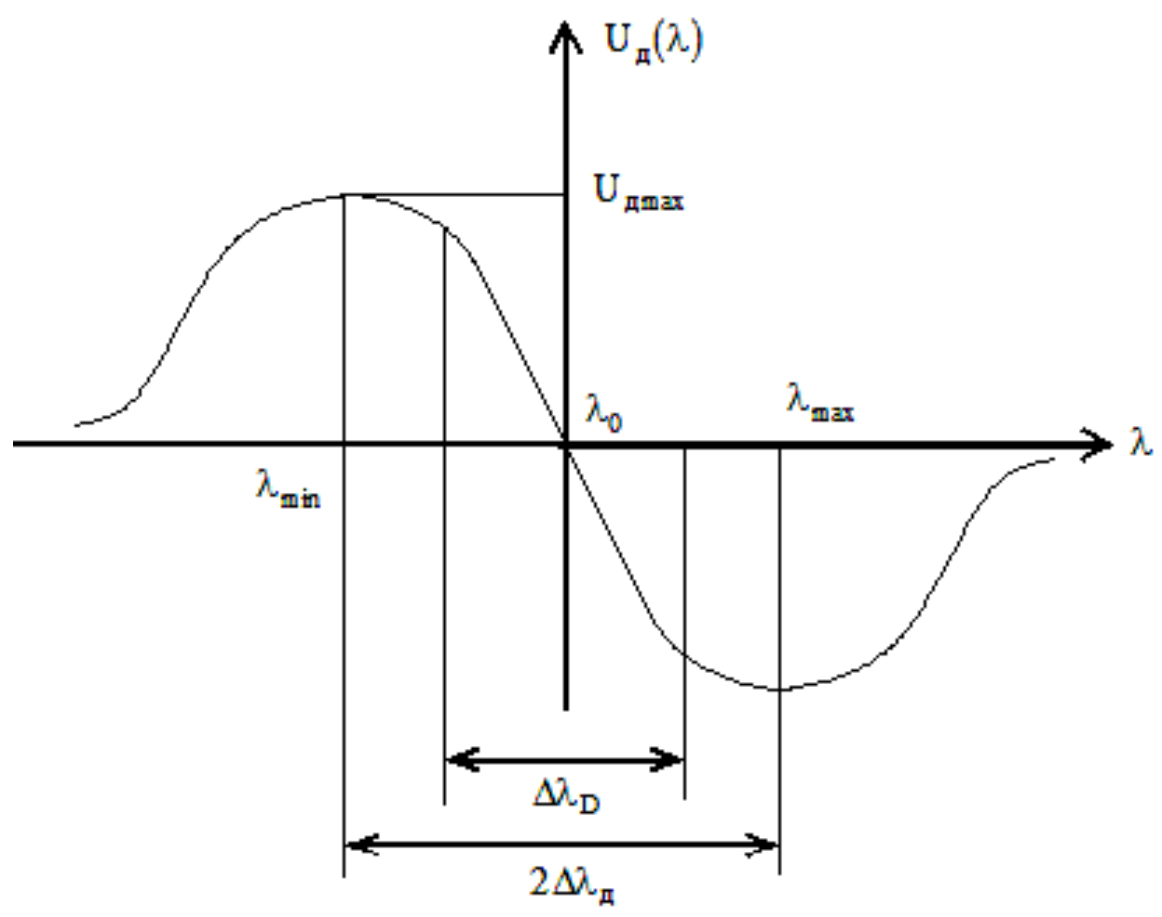

Рис. 3. Апріорний діапазон менше апертури дискримінатора

У даному випадку рівень сигналу більше потрібного. Тому, можна зменшити розстройку між каналами так, щоб діапазони зрівнялися, і тим самим без додаткового втручання збільшити крутизну дискримінатора і його точність.

Якщо уявити, що апріорний діапазон $\Delta \lambda_{D}$ перевищує фізичний діапазон, то в цьому випадку можлива неоднозначність вимірювань. Єдине оптимальне узгодження апріорного діапазону параметра, що вимірюється, 3 його фізичним діапазоном буде лише при їх дорівнюванні, тобто:

$$
2 \beta_{a \lambda} \sigma_{a \lambda}=\Delta \lambda_{D}=2 \Delta \lambda_{\partial} .
$$

Дану обставину можливо стверджувати як “невелика оптимізація”.

Таким чином, при узгоджені частотної смуги пропускання П зі спектром сигналу (2) можливо отримати оптимальність значення смуги приймача або фільтра за Сифоровим.

Можливість використання апріорних даних.

За (3) можливо підключити апріорні дані:

$$
\sigma_{\lambda}^{2}=\frac{2 \beta_{a \lambda}^{2} \sigma_{a \lambda}^{2}}{q}
$$

Відомо, якщо мати апріорний гаусів розподіл ймовірності, то можливо підвищити точність вимірювань. Для уточнення оцінки параметра $\lambda$ необхідно обчислити зважену оцінку при гаусових розподілах $p(\lambda)$ і $p_{a}(\lambda)$ :

$$
\lambda_{I}=\frac{\sigma_{a}^{-2} \lambda_{a}+\sigma_{\lambda}^{-2} \lambda}{\sigma_{a}^{-2}+\sigma_{\lambda}^{-2}} .
$$

Тоді точність зваженої оцінки підвищиться на значення апріорної точності $\sigma_{a}^{-2}$ :

$$
\sigma_{l}^{-2}=\sigma_{a}^{-2}+\sigma_{\lambda}^{-2}=\sigma_{a}^{-2}\left(1+\frac{\beta_{a \lambda}^{-2}}{2} q_{l}\right) .
$$

Це ще більш узагальнена крива (12), включає апріорні дані. При $q>20 \beta^{2}$ уточняти 
обчислення немає сенсу, оскільки точність підвищується лише на $10 \%$, що є оптимумом за типом насичення.

Таким чином, апріорні дані можуть представляти собою результати вимірювань на попередні шкали. Недолік дискримінаторів полягає у тому, що слідкують у зрівнянні 3 неслідкуючими дискримінаторами - наявність динамічної похибки.

Вплив змін рівня сигналу на точність очінювання.

Практично всі радіотехнічні дискримінатори мають таку особливість, що найбільша напруга (відлік) на виході дискримінатора, коли параметр знаходиться на межах його апертури, пропорційна амплітуді вхідного сигналу, у тому числі після обмежників i стабілізаторів його амплітуди.

Для оцінки впливу змін амплітуди сигналу, припустимо, що немає стабілізаторів і обмежників амплітуди, тоді визначимо, як це вплине на похибку дискримінатора.

Припустимо, що маємо дискримінаторну характеристику $U_{\partial}(\lambda)$, у якій максимальне значення $U_{\partial m}$ відповідає амплітуді вхідного сигналу $S_{m 2}$, (рис. 4).

Якщо амплітуда вхідного сигналу зміниться і стане $S_{m l}$, то дискримінаторна характеристика стане крутіше і їі максимум стане дорівнювати $U_{m}$, що призведе до похибки оцінки параметра сигналу $\lambda$.

Дійсно, якщо на виході дискримінатора $є$ напруга $U_{\lambda}$ і відсутня флуктуаційна завада, то вважаємо, що вимірюваний параметр дорівнює $\lambda_{1}$. При цьому, маючи на увазі, що нам відомий колишній рівень сигналу, а насправді, рівень сигналу став $S_{m 1}$, крутість дискримінаторної характеристики стала більше і напрузі $U_{\lambda}$ відповідає параметр сигналу $\lambda_{2}$.

Отже, похибка в оцінці параметра $\lambda$ дорівнює:

$$
\Delta \lambda=\lambda_{1}-\lambda_{2}=\Delta \lambda_{\partial} \frac{U_{\lambda}}{U_{m}}-\Delta \lambda_{\partial} \frac{U_{\lambda}}{U_{m l}} .
$$

Тоді:

$$
\Delta \lambda=\lambda_{\partial} U_{\lambda}\left(\frac{1}{U_{m}}-\frac{1}{U_{m 1}}\right)=\Delta \lambda_{\partial} \frac{U_{\lambda}}{U_{m}}\left(1-\frac{U_{m}}{U_{m 1}}\right) .
$$

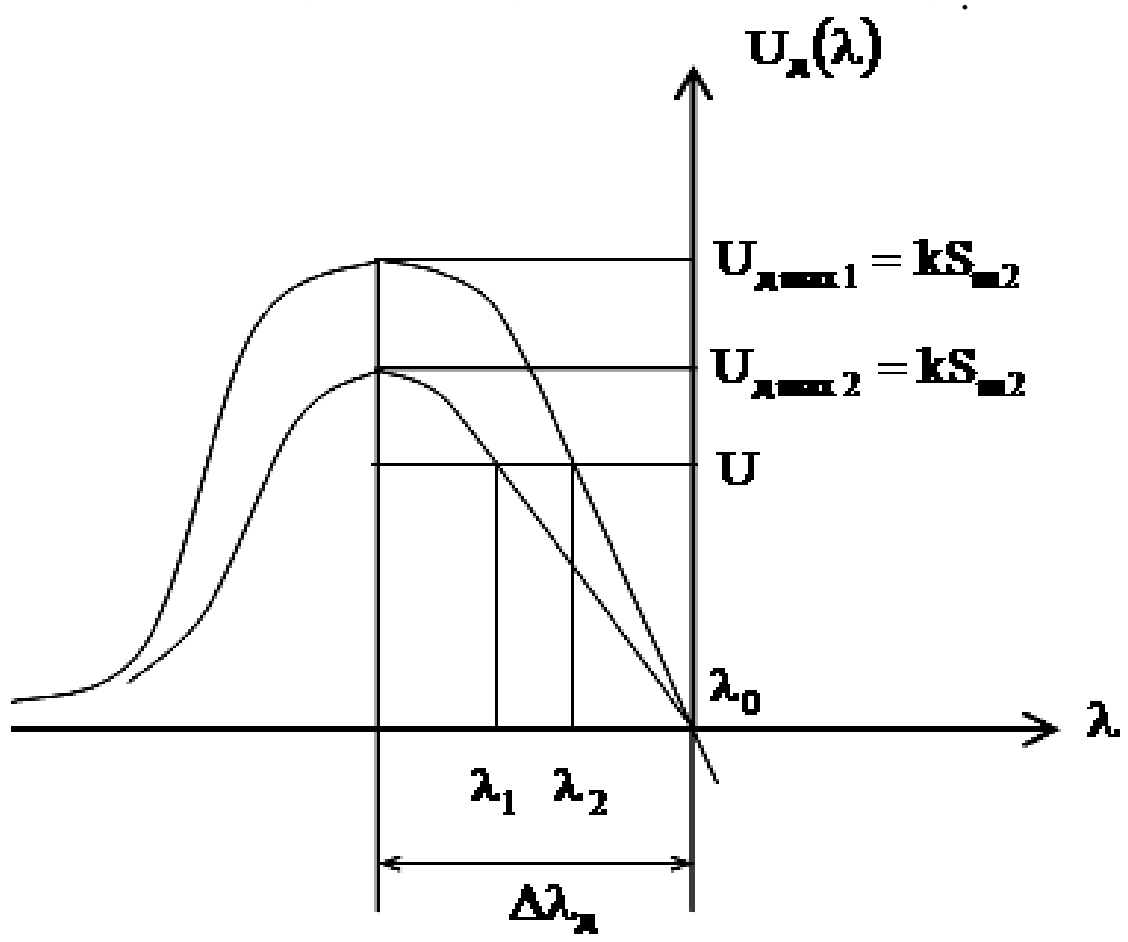

Рис. 4. Вплив рівня сигналу на вимірювання 
Якщо рівень сигналу $U_{m}-$ випадкова величина, то дисперсія $\sigma_{2}^{2}$, похибки $\Delta \lambda$ параметра сигналу за рахунок випадкової зміни амплітуди сигналу, буде дорівнювати:

$$
\sigma_{\lambda(A M)}^{2}=\Delta \lambda_{\partial}^{2}\left(\frac{U_{\lambda}}{U_{m}}\right)^{2} \hat{\sigma}_{U m}^{2}
$$

де $\widehat{\sigma}_{U m}^{2}=\left(\frac{\sigma_{u}}{U_{m}}\right)^{2}-$ відносна дисперсія амплітуди сигналу.

Таким чином, максимальна дисперсія $\sigma_{\Delta \lambda(A M)}^{2}$ похибки оцінки $\lambda$ відповідає $U_{\lambda}=U_{m}$ та дорівнює:

$$
\max _{\left\{U_{\partial}\right\}} \sigma_{\lambda(\mathrm{AM})}^{2}=\Delta \lambda \partial_{\partial}^{2} \widehat{\sigma}_{U_{m}}^{2}
$$

Нехай дисперсія $\sigma_{\lambda(A M)}^{2}$ похибки $\Delta \lambda$ (за рахунок незнання сигналу) не перевищує дисперсію вимірювань за рахунок впливу флуктуаційних завад. Тоді можливо одержати вимогу до точності стабілізації амплітуди сигналу:

$$
\sigma_{\lambda(\mathrm{MM})}^{2} \leq \sigma_{\lambda}^{2}
$$

звідси:

$$
\Delta \lambda{ }_{\partial}^{2} \sigma_{U_{m}}^{2} \leq \frac{\Delta \lambda \frac{2}{q}}{q}
$$

або:

$$
\widehat{\sigma}_{U_{m}}^{2} \leq \frac{1}{q}
$$

Отримано ще один додаток (17) до кривої обміну цільової функції (3).

Таким чином, на криві обміну дискримінаторних вимірювачів IBC значний вплив вказує точність настройки шкал, тобто, точність здвигу початку шкали.

\section{Висновки} висновки.

За результатом аналізу отриманих виразів (2) i (3) можливо зробити наступні

1. Точність вимірювання будь-якого параметра $\lambda$ сигналу не залежить від коефіцієнта підсилення приймача IBC. Однак, його обирають не довільно, а таким, щоб рівень вихідного сигналу, що повинен бути відомим, відповідав шкалі кінцевого вимірювального пристрою (вимірювача IBC).

2. Точність вимірювання параметра $\lambda$ сигналу, як величина зворотна дисперсії погрішності, прямопропорційна відношенню сигнал/шум $q$.

3. Дисперсія оцінки $\sigma_{\lambda}^{2}$ параметра $\lambda$ сигналу, відповідно до виразу (3), пропорційна квадрату апертури дискримінатора. Тому, для досягнення високої точності (малої дисперсії $\sigma_{\lambda}^{2}$ ) варто прагнути до зменшення апертури $\Delta \lambda_{2}$ дискримінатора.

4. Точність вимірювача IBC зростає також при зменшенні ширини спектра сигналу, тому фазові вимірювання вважаються найбільш точнішими.

5. Вираз (3) зв’язує всі показники якості для вимірювачів IBC. Після введення обмежень це будуть криві обміну цільової функції (якостей) вимірювачів IBC за Гуткіним Л.С. висновки.

За результатом аналізу отриманих виразів (16) і (17) можливо зробити наступні

1. Найменший вплив зміни амплітуди на похибку дискримінаторних вимірювань 
виявляється при малому відхиленні параметра від центрального настроювання дискримінатора $\lambda_{0}$, тобто при малому $U_{\partial}$. Звідси зрозуміло, що для боротьби з впливом зміни рівня сигналу найкраще використовувати вимірювач, що стежить, у якого відслідковується параметр $\lambda$. Однак, навіть для дискримінатора, що стежить, стабілізація амплітуди сигналу необхідна через те, що динаміка іiі зміни може позначатися на якості спостереження за параметром $\lambda$.

2. Стабілізація амплітуди сигналу (вимірювання її з відносною точністю):

$$
\bar{\lambda}_{U_{m}}^{2} \leq \frac{1}{q},
$$

дозволяє не враховувати похибку за рахунок незнання амплітуди сигналу. При цьому, відносна дисперсія стабілізації амплітуди порівняна з відносною дисперсією флуктуаційної складової похибки дискримінаторного вимірювача IBC:

$$
\left(\frac{\sigma_{\lambda}}{\Delta \lambda_{\partial}}\right)^{2}=\sigma_{U_{m}}^{2}=\frac{1}{q} \text {. }
$$

Це означає, що дискримінатор, який не стежить, за виразом (17), практично не поступається за точністю дискримінатору, який стежить, при однаковій ефективній смузі пропускання частотних фільтрів.

3. Перевагою дискримінаторів, що стежать, у порівнянні з дискримінаторами, які не стежать, є менший вплив зміни амплітуди сигналу.

4. Перевагою дискримінаторів, які не стежать, у порівнянні з дискримінаторами, що стежать, є відсутність динамічної похибки вимірювань параметра сигналу, яка пов'язана 3 перестроюванням дискримінатора і динамікою змін параметрів сигналу в часі.

\section{СПИСОК ЛІТЕРАТУРИ}

1. Гуткин Л.С. Оптимизация радиоэлектронных устройств по совокупности показателей качества / Л.С. Гуткин. - М., 1974. - 278 с.

2. Вудворд Ф.М. Теория вероятности и теория информации с применением в радиолокации / Ф.М. Вудворд. - М., 1968.

3. Алешин Г.В. Эффективность сложных радиотехнических систем / Г.В. Алешин, Ю.А. Богданов. - К., 2008. - 288 с.

4. Алешин Г.В. Оцінка якості інформаційно-вимірювальних систем / Г.В. Алешин. $-\mathrm{X} ., 2009 .-300 \mathrm{c}$.

5. Алешин Г.В. Ефективність інформаційно-вимірювальних радіотехнічних систем / Г.В. Алешин. - Х., $2005-294$ с.

6. Устинов Н.Д. Лазерная локация / Н.Д. Устинов. - М.: Машиностроение, 1984. - 272 с.

7. Коломийцев А.В. Информационные технологии и системы в управлении, образовании, науке: коллективная монография; под ред. В.С. Пономаренко / А.В. Коломийцев и др. - Х.: Цифрова друкарня № 1, 2013. - 278 с.

8. Алешин Г.В. Информационные системы в управлении, образовании, промышленности: коллективная монография; под ред. В.С. Пономаренко / Г.В. Алешин, А.В. Коломийцев и др. - Х.: Вид-во ТОВ “Щедра садиба плюс", 2014. - 498 с.

9. Алешин Г.В. Информационные технологии и защита информации в информационнокоммуникационных системах: коллективная монография; под ред. В.С. Пономаренко / Г.В. Алешин, А.В. Коломийцев и др. - Х.: Вид-во ТОВ “Щедра садиба плюс”, 2015. - 486 с.

10. Алешин Г.В. Информационные технологии: проблемы и перспективы: коллективная монография; под ред. В.С. Пономаренко / Г.В. Алешин, А.В. Коломийцев и др. - Х.: Вид-во Рожко С.Г., 2017. - 447 с.

11. Казаков Е.Л. Распознавание радиолокационных целей по сигнальной информации: монография; под ред. Е.Л. Казакова / Е.Л. Казаков, А.Е. Казаков, Д.Г. Васильев, 
А.В. Коломийцев, Д.Н. Рыжов. - Х.: КП “Городская типография”, 2010. - 232 с.

12. Kudriashov V. "Experimental Evaluation of Opportunity to Improve the Resolution of the Acoustic Maps". In: Kountchev R. and Nakamatsu K. (eds.), New Approaches in Intelligent Image Analysis, Intelligent Systems Reference Library 108, pp. 353-373. Springer International Publishing Switzerland 2016. DOI: 10.1007/978-3-319-32192-9_11, SJR: 0.154.

13. Малашин М.C. Основы проектирования лазерных локационных систем / М.С. Малашин и др. - М.: Высшая школа, 1983 - 297 с.

14. Молебный В.В. Оптико-локационные системы / B.В. Молебный. - М.: Машиностроение, 1981 - 184 с.

15. Каумен М. Лазерная космическая связь / М. Каумен. - М.: Радио и связь, 1993 - 240 с.

\section{Альошин Геннадій Васильович}

доктор технічних наук, професор, професор кафедри транспортного зв'язку Української державної академії залізничного транспорту, Харків, Україна

https://orcid.org/0000-0003-1876-7616

e-mail: aloshingv@gmail.com

\section{Коломійцев Олексій Володимирович}

Заслужений винахідник України, доктор технічних наук, старший науковий співробітник, начальник кафедри військового інституту танкових військ Національного технічного університету "Харківський політехнічний інститут", Харків, Україна https://orcid.org/0000-0001-8228-8404

e-mail: Alexus_k@ukr.net

\section{Бабенко Валерій Павлович}

кандидат технічних наук, доцент, професор кафедри кафедри військового інституту танкових військ Національного технічного університету "Харківський політехнічний інститут”, Харків, Україна

https://orcid.org/0000-0002-1180-1511

e-mail: babenko.v.p63@gmail.com

Топчій Владислав Леонідович,

здобувач наукового ступеня кандидата технічних наук, викладач Національної академії національної гвардії України, Харків, Україна

https://orcid.org/0000-0003-1161-545X

e-mail: tvlcomrat@gmail.com

\section{Олійник Руслан Михайлович,}

начальник науково-дослідного відділу Державного науково-дослідного інституту випробувань і сертифікації озброєння та військової техніки, Чернігів, Україна https://orcid.org/0000-0002-3969-544X e-mail: o.ruslan77@gmail.com

\section{Aloshin Gennadiy}

Doctor of Technical Sciences Professor, Professor of Transport Communications Department of the Ukrainian State Academy of Railway Transport, Kharkiv, Ukraine https://orcid.org/0000-0003-1876-7616 e-mail: aloshingv@gmail.com

\section{Kolomiitsev Oleksii}

Honored Inventor of Ukraine, Doctor of Technical Sciences, Senior Research, Chief of department Military Institute of Tank Troops of National Technical University is the "Kharkiv Polytechnic Institute", Kharkiv, Ukraine

https://orcid.org/0000-0001-8228-8404

e-mail: Alexus_k@ukr.net

\section{Babenko Valerii}

Candidate of Technical Sciences, Associate professor, Professor of department Military Institute of Tank Troops of National Technical University is the "Kharkiv Polytechnic Institute", Kharkiv, Ukraine https://orcid.org/0000-0002-1180-1511 e-mail: babenko.v.p63@gmail.com

\section{Topchii Vladislav}

bread-winner of scientific degree of candidate of engineering sciences teacher of the National academy of national household troops of Ukraine, Kharkiv, Ukraine

https://orcid.org/0000-0003-1161-545X e-mail: tvlcomrat@gmail.com

\section{Oliynik Ruslan}

Chief of Section of State Scientific Research Institute of Armament and Military Equipment Testing and Certification, Chernihiv, Ukraine https://orcid.org/0000-0002-3969-544X e-mail: o.ruslan77@gmail.com 
Збірник наукових прачь Державного науково-дослідного інституту випробувань і сертифікачії озброєння та військової техніки. 2019. Вип. № 2

ISSN 2706-7386

METHOD OF OPTIMAL SYNTHESIS OF INFORMATION MEASURING SYSTEMS

\author{
G. Aloshin, O. Kolomiitsev, V. Babenko, V. Topchii, R. Oliynik
}

The current study considers the existent problem of optimal synthesis (build-up) of the information measuring systems (IMS). The ways for solving this problem are shown by using the curves of exchange by Gutkin, L.S. These curves make it easier to understand what IMSs have more optimal parameters, how to co-ordinate the quality indices of measuring of parameters, how to meet the demand of a large expected uncertainty not diminishing the exactness of measuring, how to explain contradiction of some known theories, how to harmonise a priori range with a physical range, how to use priori data obtained, what is the impact of a changing signal level on exactness of measuring, how the accuracy of settings makes impact on exactness of measuring, how to shorten signal search time, in what way the nature of process impacts the automatic tracking etc. The offered method of IMS optimal synthesis is valid for IMS of any type of signals and parameters of measuring. Analytic expressions were used for calculations.

Exactness of any signal parameter measuring does not depend on an amplification of transceiver of IMS factor. However, it is chosen not arbitrarily, and such, that the level of initial signal to be known could correspond the the scale of eventual measuring device (measuring device of IMS). Exactness of measuring signal $\lambda$ parameter as a value that reversed to error dispersion is straight proportional to the relation signal/noise q. Dispersion of error of estimation of signal is proportional to the square of aperture of discriminator. Therefore, for the achievement of high exactness of measuring of signal it is needed to seek the diminishing aperture of discriminator. The least impact of amplitude's change on the error of the discriminator measuring appears at minor deviation of parameter from the central tuning of discriminator. Advantage of tracking discriminators comparing to non-tracking ones consists in less impact of change of signal amplitude. Advantage of non-tracking discriminators comparing to tracking ones consists in absence of the dynamic error of measuring of signal parameter that related to re-tuning of discriminator and dynamics of signal parameters changes in time.

Keywords: optimization, estimation of parameter, measuring, exactness. 